\title{
The relationship between earnings and labour productivity in textile industry
}

\section{REZUMAT - ABSTRACT}

\section{Relația dintre venituri și productivitatea muncii în industria textilă}

Veniturile și productivitatea muncii sunt indicatori economici importanți, relațiile dintre acestea fiind analizate de economiști, angajatori și factorii de decizie. Relația dintre venituri și productivitatea muncii este importantă pentru fiecare regiune sau sector economic, deoarece aceasta influențează standardul de viață și distribuția veniturilor între muncă și capital. Lucrarea analizează legătura dintre salariul mediu brut și productivitatea muncii din industria textilă în perioada 2005-2016, în România. Rezultatele analizei evidențiază că există o corelație pozitivă, dar moderată, între salariul mediu brut și productivitatea muncii. În acest scop, au fost utilizate metodele statistico-econometrice pentru a verifica normalitatea distribuției seriilor de date și existența unei corelații între indicatorii analizați.

Cuvinte-cheie: câștig, eficiență, industria textilă, câștiguri salariale medii brute, productivitate

\section{The relationship between earnings and labour productivity in textile industry}

Earnings and labor productivity are important economic indicators, the relationship between them being analyzed by economists, employers and policy makers. The relationship between earnings and labor productivity is important for each region or economic sector, because it influences the living standard and the distribution of income between labor and capital. This paper analyzes the link between gross average earning and labor productivity in the textile industry during 2005-2016 in Romania. The results of the analysis show that there is a positive, but moderate correlation between gross average earning and labor productivity. For this purpose were used statistical-econometric methods to verify the normality of data series distribution and the existence of a correlation between the indicators analyzed.

Keywords: earning, efficiency, textile industry, gross average earnings, productivity

\section{INTRODUCTION}

Wages are the main source of living for employees, accounting most of the revenues achieved and having a decisive effect on the standard of living of the employee and its family. Labor productivity is one of the indicators that show how effective the workforce is. Of all the factors of production, human capital (meaning labor) is one of the most important factors that impose effects on productivity. Increasing labor productivity means that a larger quantity of goods has been produced over a period of time in a sector or across one country.

The main objective of this paper is to verify one of the fundamental correlations in the economy, namely the link between earnings and labor productivity.

Starting from the hypothesis that there is a connection between these two indicators, the test results used in this paper confirmed a modest correlation between the two indicators, insufficient to generate the normality required in the analyzed industrial sector: the evolution of earnings to be based on the evolution of labor productivity in the textile manufacturing sector.

The paper contains a review of literature on the subject, the statistical analysis of the indicators and discussions on the results of the research and the conclusions of these results, part which is a starting point for adoption of economic policies meant to ensure high labor productivity, with positive effects on earnings within a national economy.

\section{REVIEW OF LITERATURE}

Afrooz et all (2010), in a study entitled "An analysis of gender, age and education effects on wages and productivity" noted that there is a positive relationship between productivity and real wages. Similarly, there was an increase in wage bonus with years of schooling and higher education proved to generate higher productivity [1].

Gupta (1975), in his study regarding stimulating the workforce of the Indian iron and steel industry, found that monetary incentives are the best motivations that lead to better motivation and higher labor productivity [2].

Hind (1990) claimed that direct monetary benefits, together with greater accountability and autonomy in decision-making process, had strong motivations compared to other advantages. However, non-monetary incentives are probably more important for directors, especially those who are senior positions [3]. Huizinga and Broer (2004), referring to the example in Netherlands, said that only on short term, wage growth will increase labor productivity, but on the long term it will have no impact [4].

Klein's study (2012) showed that the absence of a strong relationship between wages and labor productivity in some countries can be explained by macroeconomics and/or institutional factors. These factors tend to create a barrier between the two variables, which means that earnings from labor productivity do 
not fully lead to an increase of real wages (or vice versa) on short or long term [5].

\section{ANALYSIS AND DISCUSSION}

The database for the analysis of the relationship between gross average earning and labor productivity in the textile manufacturing industry in Romania includes data with annual frequency and was built during 2005-2016. The information and statistical data related to the monthly gross average earnings and labor productivity were taken from the National Statistics Institute, based on tempo-online data series. For empirical research, the 2005-2016 period was chosen in order to achieve meaningful and reliable results.

In order to capture the link between gross average earning and labor productivity, but also to understand the methodological approach, we considered necessary to present the dynamics of the explanatory variables during the analyzed period (table 1 and table 2) [6].

Another step in the econometric analysis is the presentation of the statistical descriptions of the instrumental variables included in the model.

Thus, based on the data from tables 1 and 2, we have presented for the two indicators analyzed the descriptive statistics (standard deviation, Skewess and Kurtosis indicators to see the deviation of the empirical distribution in relation to a symmetric distribution around the mean and the degree of flattening or sharpening of data distribution), as can be seen in table 3 [7].

We checked the distribution normality using as instruments graphical tools as Q-Q Plot and KolmogorovSmirnov (as parametric methods) and graphs as

Table 1

\begin{tabular}{|l|c|c|c|c|c|c|c|c|c|c|c|c|}
\hline \multicolumn{10}{|c|}{ MONTHLY GROSS AVERAGE EARNINGS IN TEXTILE INDUSTRY } \\
\hline Year & Jan & Feb & Mar & Apr & May & Jun & Jul & Aug & Sep & Oct & Nov & Dec \\
\hline $\mathbf{2 0 0 5}$ & 590 & 592 & 622 & 620 & 629 & 659 & 677 & 675 & 667 & 683 & 710 & 758 \\
\hline $\mathbf{2 0 0 6}$ & 667 & 660 & 707 & 686 & 737 & 755 & 765 & 778 & 767 & 788 & 812 & 838 \\
\hline $\mathbf{2 0 0 7}$ & 814 & 833 & 880 & 843 & 892 & 921 & 924 & 927 & 936 & 983 & 1015 & 1068 \\
\hline $\mathbf{2 0 0 8}$ & 979 & 972 & 1008 & 1043 & 1045 & 1095 & 1132 & 1084 & 1106 & 1158 & 1129 & 1205 \\
\hline $\mathbf{2 0 0 9}$ & 1157 & 1155 & 1240 & 1249 & 1261 & 1288 & 1283 & 1197 & 1289 & 1343 & 1363 & 1490 \\
\hline $\mathbf{2 0 1 0}$ & 1352 & 1394 & 1486 & 1389 & 1425 & 1468 & 1491 & 1416 & 1470 & 1528 & 1515 & 1784 \\
\hline $\mathbf{2 0 1 1}$ & 1523 & 1519 & 1623 & 1561 & 1560 & 1624 & 1609 & 1503 & 1590 & 1607 & 1624 & 1786 \\
\hline $\mathbf{2 0 1 2}$ & 1559 & 1554 & 1608 & 1595 & 1631 & 1683 & 1671 & 1578 & 1688 & 1691 & 1721 & 1815 \\
\hline $\mathbf{2 0 1 3}$ & 1605 & 1632 & 1719 & 1733 & 1732 & 1850 & 1841 & 1708 & 1764 & 1774 & 1831 & 2010 \\
\hline $\mathbf{2 0 1 4}$ & 1767 & 1802 & 1876 & 1839 & 1858 & 1960 & 1979 & 1821 & 1883 & 1893 & 1986 & 2129 \\
\hline $\mathbf{2 0 1 5}$ & 1809 & 1835 & 1922 & 1890 & 1883 & 1992 & 2030 & 1847 & 1947 & 1978 & 2110 & 2253 \\
\hline $\mathbf{2 0 1 6}$ & 2011 & 2042 & 2140 & 2130 & 2214 & 2357 & 2343 & 2264 & & & & \\
\hline
\end{tabular}

Table 2

\begin{tabular}{|c|c|c|c|c|c|c|c|c|c|c|c|c|}
\hline \multicolumn{13}{|c|}{$\begin{array}{c}\text { LABOR PRODUCTIVITY IN TEXTILE INDUSTRY } \\
\text { Unit: percent }\end{array}$} \\
\hline Year & Jan & Feb & Mar & Apr & May & Jun & Jul & Aug & Sep & Oct & Nov & Dec \\
\hline 2005 & 63.8 & 68.3 & 74.8 & 69.0 & 67.6 & 78.4 & 67.1 & 56.1 & 76.6 & 74 & 75.1 & 59.1 \\
\hline 2006 & 68 & 65.8 & 81.3 & 60.4 & 71.1 & 71.3 & 62 & 52.5 & 65.3 & 74.7 & 76.1 & 64.0 \\
\hline 2007 & 82.4 & 81.8 & 87.6 & 69.7 & 82.6 & 75.9 & 86.6 & 58.6 & 76.9 & 87.8 & 87.7 & 65.2 \\
\hline 2008 & 76.7 & 89.8 & 83.2 & 80.9 & 76.5 & 89.0 & 90.5 & 68.0 & 90.5 & 94.8 & 89.6 & 78.4 \\
\hline 2009 & 77.7 & 74.7 & 83.5 & 76.7 & 76.2 & 76.6 & 79.0 & 67.5 & 98.7 & 112.1 & 104.2 & 90.8 \\
\hline 2010 & 94.7 & 107 & 117.9 & 99.6 & 89.0 & 93.6 & 92.3 & 75.0 & 108.1 & 112.4 & 119.4 & 89.8 \\
\hline 2011 & 110.1 & 106.7 & 118.5 & 100.6 & 103.7 & 88.9 & 85.7 & 75.0 & 102.4 & 101.6 & 107.3 & 91.5 \\
\hline 2012 & 98.2 & 114.1 & 110.2 & 85.7 & 100.0 & 87.9 & 74.9 & 66.1 & 91.1 & 110.2 & 110.0 & 77.3 \\
\hline 2013 & 99.5 & 108.3 & 115.8 & 101.9 & 88.3 & 80.1 & 86.1 & 72.8 & 100.9 & 107.0 & 104.5 & 89.2 \\
\hline 2014 & 109.70 & 103.60 & 99.30 & 86.70 & 99.10 & 89.30 & 85.20 & 64.20 & 93.10 & 94.50 & 92.90 & 77.30 \\
\hline 2015 & 82.2 & 85.0 & 86.9 & 74.4 & 66.2 & 69.5 & 76.1 & 51.8 & 84.1 & 90.3 & 84.9 & 71.2 \\
\hline 2016 & 78.4 & 83.8 & 85.4 & 72.1 & 72.5 & 72.1 & 66.4 & 59.1 & & & & \\
\hline
\end{tabular}


DESCRIPTIVE ANALYSIS OF VARIABLES GROSS AVERAGE EARNINGS AND LABOR PRODUCTIVITY

\begin{tabular}{|l|r|r|r|r|r|r|r|r|r|}
\hline & \multicolumn{1}{|c|}{ N } & \multicolumn{1}{c|}{ Min } & \multicolumn{1}{c|}{ Max } & \multicolumn{1}{c|}{ Mean } & Std. Deviation & \multicolumn{2}{|c|}{ Skewness } & \multicolumn{2}{c|}{ Kurtosis } \\
\cline { 2 - 11 } & Statistic & Statistic & Statistic & Statistic & Statistic & Statistic & Std. Error & Statistic & Std. Error \\
\hline Gross average earning & 140 & 590.00 & 2357.00 & 1412.7071 & 476.47261 & -.141 & .205 & -1.102 & .407 \\
\hline Labour productivity & 140 & 51.80 & 119.40 & 84.9214 & 15.52712 & .228 & .205 & -.629 & .407 \\
\hline Valid N (listwise) & 140 & & & & & & & & \\
\hline
\end{tabular}

Boxplot $(1,2,3)$ to identify aberrant values in data series.

Figure 1 presents the $Q-Q$ Plot for gross average earnings data series and it can be seen that the values of earnings variable closely follow the normal distribution (the deviations observed are insignificant). Figure 2 presents the Q-Q Plot for labor productivity data series and it also can be noticed that the values of the productivity labour variable follow closely the normal distribution (the deviations observed are insignificant).

The hypothesis that the gross average earnings and labour productivity variables are normal is strengthened by the Kolmogorov-Smirnov test ( $p$ values are much higher than $0.01-0.210$ for gross average earnings and 0.377 for labour productivity), as can be seen in table 4.

From QQ plot analysis (figure 1 and figure 2), boxplots (figure 3 ) and the significance levels obtained in the KS test $(0.210$ and 0.377$)$ we deduce that there is insufficient data to conclude that the gross average earnings and labor productivity variables would not be normally distributed. So, for the current analysis, we can assume that the gross average earnings and labor productivity variables are normally distributed, with the parameters estimated in the table above.

Next, we want to identify the existence of linear associations between the gross average earnings and labor
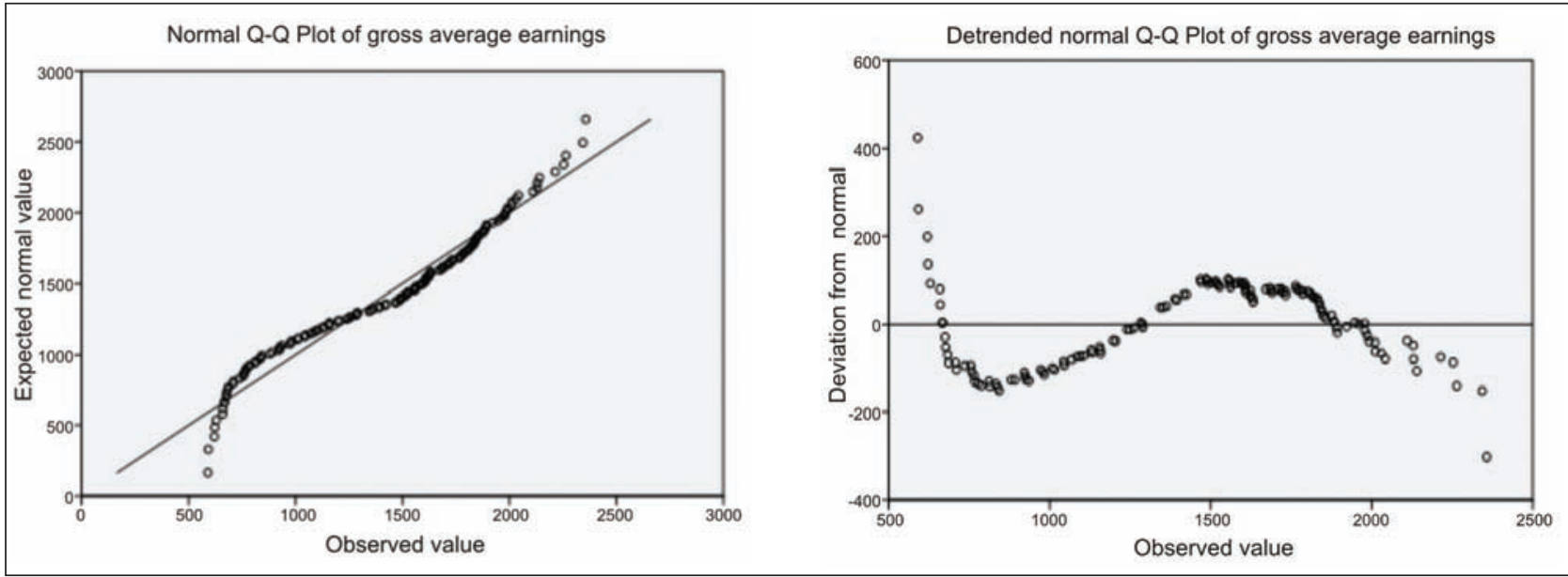

Fig. 1. Q-Q plot for Gross average earnings variable
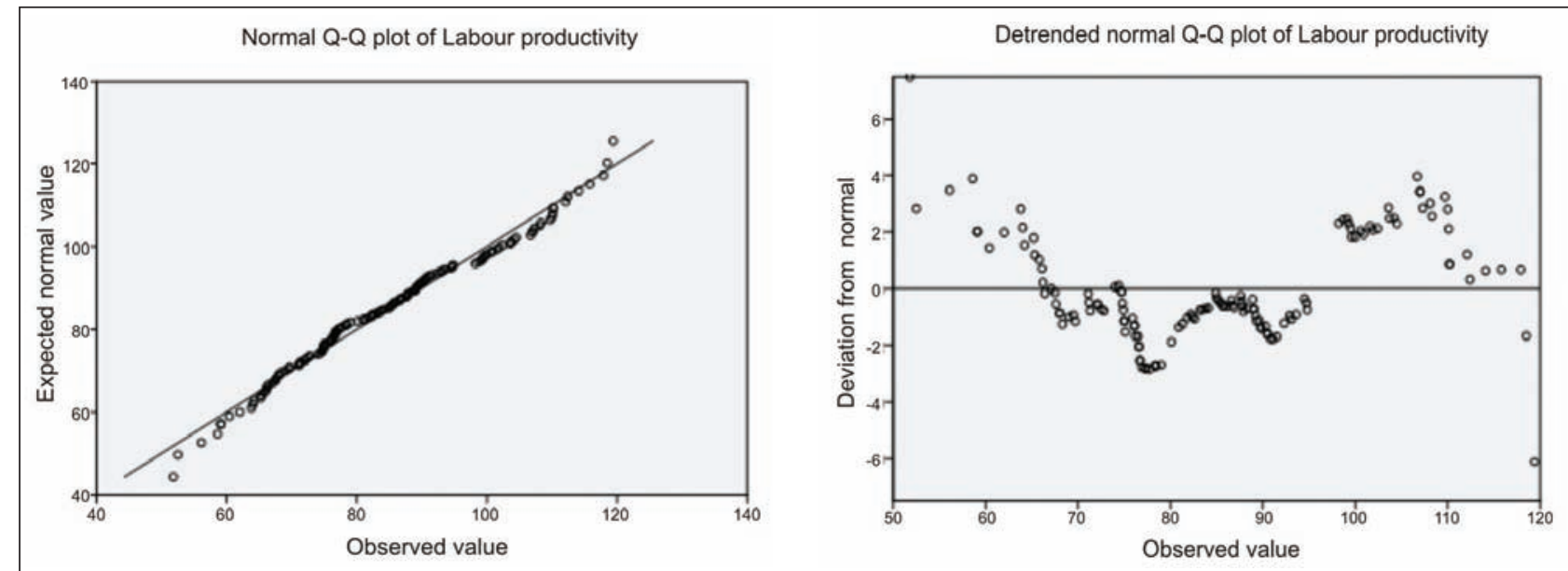

Fig. 2. Q-Q plot for Labour productivity variable 


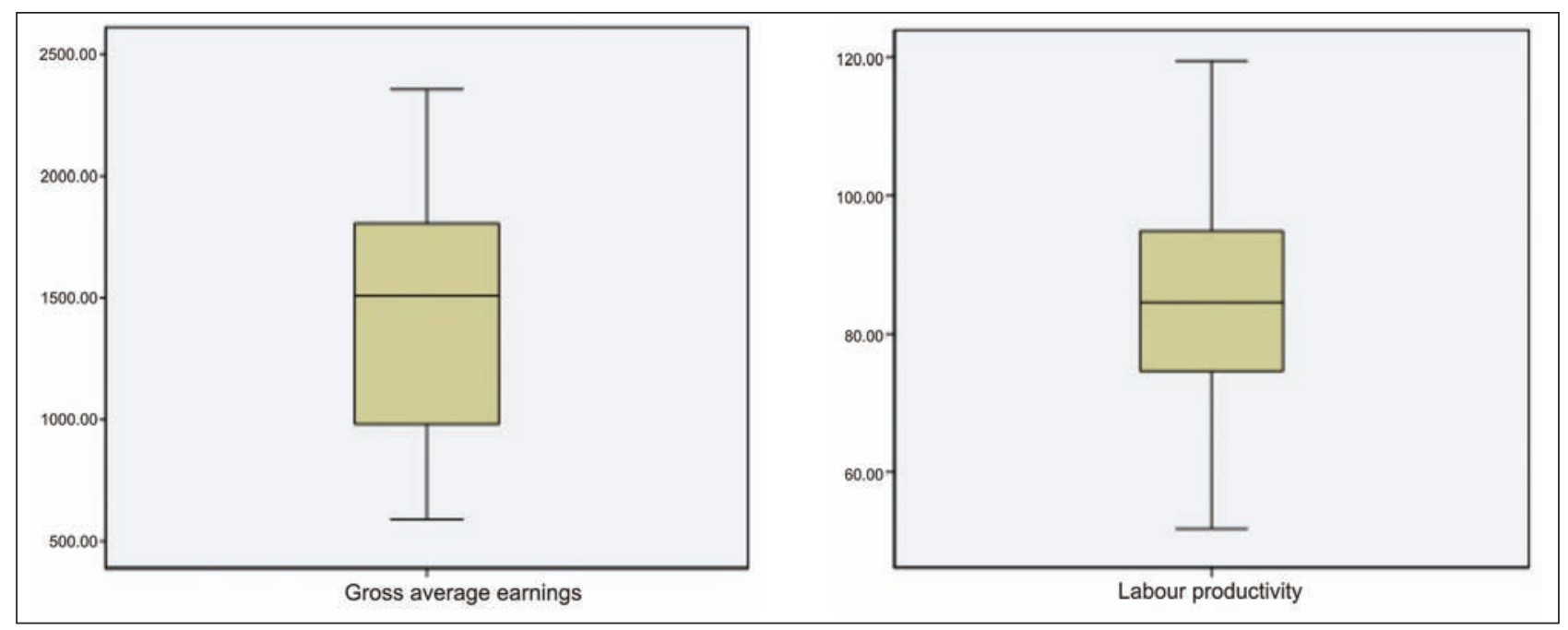

Fig. 3. Boxplots for the gross average earnings and labor productivity variables

Table 4

\begin{tabular}{|l|l|r|r|}
\hline \multicolumn{2}{|l|}{ RESULTS OF THE KOLMOGOROV-SMIRNOV TEST } \\
\hline \multicolumn{2}{|l|}{} & $\begin{array}{c}\text { Gross average } \\
\text { earnings }\end{array}$ & $\begin{array}{c}\text { Labour } \\
\text { productivity }\end{array}$ \\
\hline $\mathrm{N}$ & 140 & 140 \\
\hline \multirow{2}{*}{$\begin{array}{l}\text { Normal } \\
\text { parameters }\end{array}$} & Mean & 1412.7071 & 84.9214 \\
\cline { 2 - 4 } & $\begin{array}{l}\text { Std. } \\
\text { Deviation }\end{array}$ & 476.47261 & 15.52712 \\
\hline \multirow{2}{*}{$\begin{array}{l}\text { Most extreme } \\
\text { differences }\end{array}$} & Absolute & .090 & .077 \\
\cline { 2 - 4 } & Positive & .077 & .077 \\
\cline { 2 - 4 } & Negative & -.090 & -.048 \\
\hline Kolmogorov-Smirnov Z & 1.061 & .912 \\
\hline \multicolumn{2}{|l|}{ Asymp. Sig. (2-tailed) } & .210 & .377 \\
\hline
\end{tabular}

a Test distribution is Normal.

b Calculated from data.

productivity variables in textile industry. Therefore, in the following it is analyzed the value of Pearson correlation coefficient, used to measure and describe the degree of linear association between two normally distributed variables.
According to the data presented in table 5, Pearson correlation coefficient is 0.335 . The significance level is $<0.05$, so the correlation coefficient is significant. Variables are positively correlated, but not strongly correlated. We can deduce that there is a linear association between the two variables, but there may also be non-linear associations. Association is positive (gross average earning tends to grow along with labour productivity), but the magnitude of the association is moderate.

Starting from all the statistical data analyzed above, we can identify a correlation between gross average earning and labor productivity by estimating an econometric model. The result of the linear regression model for gross average earnings depending on labor productivity is represented in figure 4

As we have shown, association is a positive one (gross average earning tends to grow along with labour productivity), but the magnitude of the association is moderate. Therefore, we also take into consideration the nonparametric correlation coefficients Kendall and Spearman. These indicators aim to highlight the degree of association between the analyzed variables.

\begin{tabular}{|l|l|r|r|}
\hline \multicolumn{4}{|c|}{ PEARSON CORRELATION COEFFICIENT } \\
\hline \multirow{4}{*}{$\begin{array}{c}\text { Gross average } \\
\text { earnings }\end{array}$} & \multicolumn{1}{c|}{ Correlations } & Gross average earnings & \multicolumn{1}{c|}{ Labour productivity } \\
\hline & Pearson Correlation & 1 & $.335^{* *}$ \\
\cline { 2 - 4 } & Sig. (1-tailed) & & .000 \\
\cline { 2 - 4 } & Sum of Squares and Cross-products & $3.156 \mathrm{E} 7$ & 344456.179 \\
\cline { 2 - 4 } & Covariance & 227026.151 & 2478.102 \\
\cline { 2 - 4 } & $\mathrm{N}$ & 140 & 140 \\
\hline \multirow{5}{*}{$\begin{array}{l}\text { Labour } \\
\text { productivity }\end{array}$} & Pearson Correlation & $.335^{* *}$ & 1 \\
\cline { 2 - 4 } & Sig. (1-tailed) & .000 & 33511.716 \\
\cline { 2 - 4 } & Sum of Squares and Cross-products & 2478.102 & 241.091 \\
\cline { 2 - 4 } & Covariance & 140 & 140 \\
\cline { 2 - 4 } & N & 34456.179 & \\
\hline
\end{tabular}

\footnotetext{
${ }^{* *}$ Correlation is significant at the 0.01 level (1-tailed).
} 
ANALYSIS OF KENDALL AND SPEARMAN CORRELATION COEFFICIENTS

\begin{tabular}{|c|c|c|c|c|}
\hline \multicolumn{5}{|c|}{ ANALYSIS OF KENDALL AND SPEARMAN CORRELATION COEFFICIENTS } \\
\hline & Correlations & & Gross average earnings & Labour productivity \\
\hline \multirow[t]{6}{*}{ Kendall's tau_b } & \multirow{3}{*}{$\begin{array}{l}\text { Gross average } \\
\text { earnings }\end{array}$} & Correlation Coefficient & 1.000 & $.207^{*}$ \\
\hline & & Sig. (1-tailed) & & .000 \\
\hline & & $\mathrm{N}$ & 140 & 140 \\
\hline & \multirow{3}{*}{ Labour productivity } & Correlation Coefficient & $.207^{* *}$ & 1.000 \\
\hline & & Sig. (1-tailed) & .000 & \\
\hline & & $\mathrm{N}$ & 140 & 140 \\
\hline \multirow[t]{6}{*}{ Spearman's rho } & \multirow{3}{*}{$\begin{array}{l}\text { Gross average } \\
\text { earnings }\end{array}$} & Correlation Coefficient & 1.000 & $.311^{*}$ \\
\hline & & Sig. (1-tailed) & & .000 \\
\hline & & $\mathrm{N}$ & 140 & 140 \\
\hline & \multirow{3}{*}{ Labour productivity } & Correlation Coefficient & $.311^{* *}$ & 1.000 \\
\hline & & Sig. (1-tailed) & .000 & \\
\hline & & $\mathrm{N}$ & 140 & 140 \\
\hline
\end{tabular}

** Correlation is significant at the 0.01 level (1-tailed).

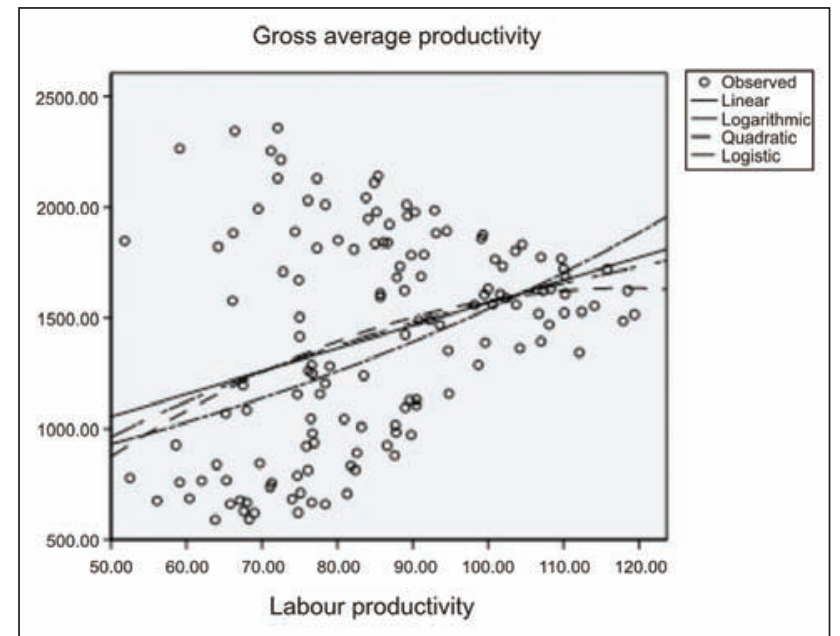

Fig. 4. The linear regression model for gross average earnings according to labour productivity

According to the data from table 6 , the nonparametric correlation coefficients, Kendall and Spearman, are also positive and statistically significant $(p<0.01)$, but do not denote a strong correlation between the two variables (they do not approach value 1).

\section{CONCLUSIONS}

In this paper we wanted to analyze whether one of the fundamental correlations in the economy - the correlation between gross average earnings and labor productivity - was respected in the textile industry.
Following the analysis of the two indicators, we can say that there is a positive association between gross average earnings and labor productivity, but the magnitude of the association is moderate, thus concluding that the evolution of earnings in the textile manufacturing industry was not based closely on the evolution of labor productivity. There is a moderate association between gross average earnings and labor productivity, so a correlation, but the evolution of gross average earnings was based on other causes and not, as it should have, on labor productivity. This has negative effects on inflation, living standards, economic equilibrium.

The link between labor productivity and wage has a positive effect on the economy, as it provides an incentive for workers to increase production. An increase in productivity leads to a higher supply on the market, which determines lower prices. Therefore, this would also influence consumers in a beneficial way. Increasing productivity would increase exports. This would also be beneficial to a country's economy. If wages are related to qualitative productivity, the quality of production would also be high.

In a future paper, we intend to study the bilateral relationship between the two variables analyzed in the present paper and to identify the factors that underlie the evolution of earnings in the economy, by testing the intensity of the relationship between them and the analyzed indicator.

\section{BIBLIOGRAPHY}

[1] Afrooz, A., Rahim, K.B.A., Noor, Z.B.M., Chin, L. A review of effects of gender, age, and education on wage and productivity, In: International Research Journal of Finance and Economics, 2010, vol. 2, no 4, pp. 47-51.

[2] Gupta, B. Labour incentive in India of iron and steel industry, In: Research Abstract Quarterly, 1975, pp. $171-176$.

[3] Hind, M. Developing the employment package: Attracting and retaining the best employees, In: Management Decision, 1990, vol. 28, no 6. 
[4] Huizinga, F., Broer, P. Wage moderation and labour productivity, In: Netherlands Bureau for Economic Policy Analysis, Series CPB Discussion, 2004, Papers 28, pp. 28-34.

[5] Klein, N. Real wage, labour productivity and employment trends in South Africa: a closer look, In: IMF Working Paper, 2012, No.12/92, pp. 1-27.

[6] INSSE Monthly Statical Bulletin, 2016 [online] Available at http://statistici.insse.ro/shop/index.jsp?page= tempo3\&lang=ro\&ind=FOM107D

[7] IBM Corp. Released 2013. IBM SPSS Statistics for Windows, Version 22.0. Armonk, NY: IBM Corp.

\section{Authors:}

\section{NORINA POPOVICI ${ }^{1}$, CAMELIA MORARU², IRENA MUNTEANU ${ }^{3}$}

1,3 “Ovidius" University, Faculty of Economic Sciences, Department of Business Administration, University Alley, No.1, Campus, 900470, Constanta, Romania

e-mail: norinapopovici@yahoo.com, irena.munteanu@yahoo.com

2 "Dimitrie Cantemir" Christian University, Faculty of Tourism and Commercial Management, Department of Business Administration, Dezrobirii Street, No 90A, 900372, Constanta, Romania e-mail: cami.moraru@yahoo.com

\section{Corresponding author:}

\section{NORINA POPOVICI}

e-mail: norinapopovici@yahoo.com

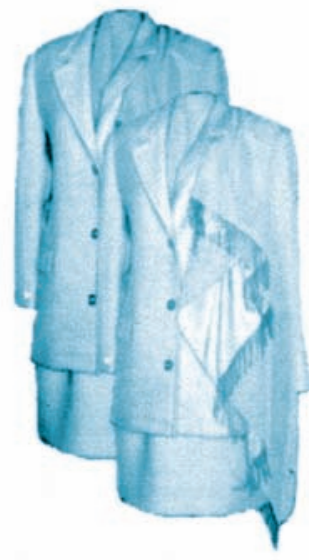

